\title{
Peran Core Self Evaluation dalam Memprediksi Persipan Pensiun
}

Arini Widyowati dan Noor Rochman Hadjam

Fakultas Psikologi ,Universitas Ahmad Dahlan ,Jl. Kapas No.9 Yogyakarta 55166.

Fakultas Psikologi ,Universitas Gadjah Mada, Jl.Humaniora No.1 Bulaksumur Yogyakarta 55281

arini.widyowati@psy.uad.ac.id

\begin{abstract}
This study examines the role of core self evaluation on predicting retirement preparation of pre retirement employees. This research involves 50 pre retirement employee of the exploration section of "X Company" who get pre retirement program on 2013. Retirement preparation scale is used to measure effort of the employee's retirement planning and core self evaluation is measured through core evaluation scale. Results show that there is no significant effect of core self evaluation on retirement preparation $(\mathrm{F}=0.581, \mathrm{p}=0.679, \mathrm{p}>0.05)$. Based on data analysis it indicated that core self evaluation does not have effect on retirement preparation. It's mean that core self evaluation could not predict employee's retirement preparation. Thera are non-motivational and cultural factors that affect employees' intention on retirement preparation.
\end{abstract}

Keywords: core self evaluation, emotional stability, self esteem, self efficacy, locus of control, retirement preparation

\begin{abstract}
ABSTRAK
Penelitian ini bertujuan untuk mengetahui untuk mengetahui peran faktor Core Self Evaluation sebagai prediktor persiapan pensiun pada karyawan. Subjek penelitian ini adalah karyawan PT. X wilayah kerja Indonesia Blok Explorasi yang memasuki usia dewasa madya antara 50 - 55 tahun dan sudah memasuki masa persiapan pension (MPP) pada tahun 2013 dengan masa kerja antara 25-30 tahun. Pengumpulan data yang digunakan dalam penelitian ini adalah skala persiapan pension dan skala core self evaluation. Analisis dilakukan dengan menggunakan teknik regresi dengan bantuan komputasi statistik program SPSS 13.00 for Windows. Hasil analisis regresi menunjukkan koefisien regresi $\mathrm{F}=0,581$ dengan taraf signifikansi 0,679 $(p>0,05)$. Hal ini menunjukkan bahwa tidak ada pengaruh core self evaluation terhadap persiapan pension. Berdasarkan hasil analisis data dapat disimpulkan bahwa core self evaluation tidak dapat memprediksi persiapan pension pada karyawan. Terdapat faktor-faktor non motivasional dan faktor budaya yang mempengaruhi persiapan pension pada karyawan.
\end{abstract}

Kata Kunci :core self evaluation, emotional stability, Locus of control, self esteem, self efficacy, persiapan pensiun. 


\section{PENDAHULUAN}

Pensiun merupakan tahapan akhir perjalanan karir individu disebuah organisasi atau perusahaan. Pensiun dapat terjadi pada individu setelah masa kerjanya berakhir atau individu yang bersangkutan memutuskan untuk berhenti atas kemauan sendiri sebelum masa kerjanya berakhir. Pada masa ini individu tidak lagi terlibat pada peran, tanggung jawab maupun tugas-tugas rutin sebagaimana layaknya seorang karyawan.

Kebijakan mengenai pensiun berbedabeda pada tiap negara, meskipun demikian pada umumnya terjadi pada individu ketika memasuki usia dewasa. Di Indonesia peraturan mengenai usia pensiun diatur dalam peraturan menteri tenaga kerja. Dalam peraturan tersebut disebutkan bahwa usia pensiun bagi pegawai pemeritahan adalah 55 tahun, dengan harapan bahwa individu dapat melanjutkan karirnya diluar hingga usia 65 tahun. Sedangkan di sektor swasta tidak ada kebijakan pasti mengenai usia pensiun, tetapi pada umumnya mereka mengikuti kebijakan pemerintah dengan menetapkan usia pensiun antara 55 - 60 tahun. Meskipun demikian individu yang memiliki kualifikasi baik dapat bekerja hingga usai 60- 65 tahun (Brojonegoro \& Simandjuntak, 2002).

Individu yang memasuki usia 55 tahun berada dalam tahap perkembangan madya dewasa. Pada tahap ini individu dituntut untuk dapat menyesuaikan diri dengan masa pensiun dan berkurangnya penghasilan(Havighurst dalam Hurlock, 1980). Berbeda dengan Havighurst, Erickson menjelaskan bahwa pada tahap dewasa akhir, individu berada dalam dalam konflik integrity (integriti) dan despair (putus asa). Integritas adalah perasaan utuh, yang merupakan kemampuan untuk menyatukan keakuan. Sedangkan putus asa adalah perasaan ketidakmampuan ketika individu mendapat tekanan (Hurlock, 1980).

Pensiun sebenarnya merupakan fenomena alami dalam kehidupan manusia. Penurunan kemampuan fisik, mental terjadi seiring bertambahnya usia yang berdampak pada produktivitas kerja karyawan. Kementrian bidang kesejahteraan rakyat (2012) dalam situs resminya menyebutkan bahwa populasi penduduk usia pensiun di Indonesia diperkirakan sebesar 23,9 juta atau 9,77\% dari seluruh penduduk Indonesia pada tahun 2010 dan diperkiraan akan mencapai 28,8 juta atau 11,34\% di tahun 2020 .

Pensiun dipandang sebagai masa transisi yang disertai dengan tekanan atau masa untuk melanjutkan bahkan meningkatkan kesejahtraan hidup. Ketika individu memasuki masa pensiun dipandang bahwa mereka telah memasuki masa dewasa. pensiun dari pekerjaan utama dapat menjadi kunci perubahan bagi kehidupan individu baik secara psikologis maupun social. Menurut Kim dan Moen (2011) Pada masa ini perubahan peran, perubahan hubungan interpersonal dan perubahan dalam aktivitas rutin terjadi seiring dengan perubahan pendapatan dan kekayaan. Masa transisi tersebut mempengaruhi bagaimana individu mempersepsi dirinya sendiri, persepsi terhadap kemampuannya dan kualitas kehidupan kerjanya.

Menurut Wotherspoon ( 1995)Transisi peran ketika memasuki pensiun dapat menjadi saat-saat yang sulit bagi individu, ketakuatan akan kehilangan pendapatan, kontrol dan vitalitas, harga diri, kehilangan mimpi dan tujuan bahkan berdampak pada ketidakmampuan dan kematian. Individu yang memasuki masa pensiun dari karir atau pekerjaannya, lebih rentan memiliki persaan tidak memiliki peran yang penting dan perasaan-perasaan lain yang mengarah pada tekanan psikologis Kim dan Moen (2001)

Berbagai perubahan yang dialami pada masa transisi ini mengakibatkan beberapa permasalahan pada pensiunan. Kim dan Moen (2002), Gill dkk (2006) menyebutkan beberpa permasalahan yang dialami individu seperti permasalahan atau penurunan kesehatan dan 
kesejehateraan psikologis setelah pension. Penelitian lain yang dilakukan oleh Gill, dkk (2006) menyebutkan bahwa individu yang pensiun lebih rentan mengalami gangguan kesehatan metal dibandingkan dengan individu yang masih bekerja.

Bagi beberapa individu pension dapat menjadi pengalaman hidup yang negative, akan tetapi bagi beberapa individu lain pension justru menjadi pengalaman hidup yang postif dan berhubungan dengan kepuasan karena dipandang sebagai pereode pertumbuhan dan perkembangan, masa penting yang berhubungan dengan gaya hidup yang berkaitan dengan kesempatan untuk bersenang-senang dalam keberhasilan menyeusikan diri dengan pension (Sethepen, Fouqereau, Fernandez. 2008). Moen (1996) menyebutkan bahwa proses pension mungkin berbeda-beda pada tiap individu dan membawa dampak yang berbeda-beda pula. Beberapa penelitian membuktikan bahwa terjadi peningkatan kesehatan, kesejahteraan, kesehatan mental pada karyawan yang pension (Kim dan Moen (2001), Mein, dkk (2003).

Salah satu faktor yang mempengaruhi keberhasilan individu menyesuaikan diri pada masa ini adalah perencanaan pensiun. Perencanaan pensiun merupakan besarnya usaha yang dilakukan oleh individu ketika masih menjadi karyawan untuk menghasilkan kesejehteraan hidup pada masa pensiun (Muratore \& Earl, 2010). Antonelis (2007) menyebutkan bahwa depresi sering terjadi pada individu yang memasuki masa pesiun tanpa perencanaan, beberapa individu juga terlibat pada penyalagunaan obat dan ketergantungan alcohol.

Salah satu organisasi yang cukup memperhatikan kesejahteraan karyawan adalah PT.X. PT. X merupakan perusahaan publik di Indonesia yang bergerak dalam bidang energi terintegrasi. Dengan bidang usaha eksplorasi dan produksi minyak dan gas bumi, industri hilir: produksi LPG distribusi bahan bakar disel dan pembangkit tenaga listrik. Setiap tahun, beberapa karyawan telah memasuki masa pensiunnya. Beberapa usaha dilakukan oleh perusahaan dalam mempersiapkan karyawan menghadapi pension melalui tunjangan hari tua, pelatihan pra pension dan perpanjangan masa kerja bagi pensiunan. Sejauh ini partisipasi karyawan sebatas mengukiti program yang telah disediakan oleh perusahaan. Karyawan belum banyak melakukan persiapan secara mandiri dalam mempersiapkan pensiunnya dengan alasan sudah difasilitasi oleh perusahaan dan masa pension masih beberapa tahun lagi. Selain itu karyawan juga belum banyak memanfaatkan fasilitas pemerintah bagi warga negara usia lanjut. Persiapan pension akan membantu katyawan untuk menyesuaikan diri pada masa pensiunnya. Keberhasilan pelaksanaan perencanaan pension sangat ditentukan oleh besarnya usaha yang dilakukan olah karyawan dalam mengikuti program yang ada serta usaha yang dilakukan oleh karyawan secara mandiri dalam mempersiapkan pensiunnya.

Salah satu faktor yang mempengaruhi persiapan pensiun yang dilakukan oleh individu adalah Core Self Evaluation. Core self evaluation adalah merupakan tingkatan dimana individu menyukai atau tidak menyukai diri sendiri, menganggap diri efektif, cakap dan mampu mengendalikan lingkungan (Judge, dkk , 2003). Inidividu dengan CSE yang tinggi akan melakukan usaha yang lebih besar untuk menyiapkan pensiunnya. Individu yang memiliki evaluasi atau penilaian diri yang positif atas dirinya akan mampu menghargai dirinya, memiliki keyakinan akan bahwa dirinya mampu menghadapi masa pension dan memiliki kemampuan untuk mengatasi permasalahan dan tetap tenang menghadapi masa pensiun. Keyakinan bahwa dirinya yang menentukan nasibnya akan membuatnya melakukan usahausaha yang lebih untuk menyiapkan diri menghadapi masa pension.

Sangat penting bagi individu untuk menyiapkan diri menghadapi masa pensiun yang 
berhubungan dengan kegiatan bersenang-senang, kesehatan, hubungan interpersonal dan pekerjaan untuk memastikan kesejahteraan dimasa pensiunnya Petkoska \& Earl (2009). Akan tetapi sejauh ini penelitian mengenai perencanaan atau persiapan pensiun lebih banyak focus pada aspek financial dan menggunakan waktu luang serta mengabaikan faktor-faktor lain seperti kesehatan, hubungan interpersonal, bekerja secara sukarela atau bekerja karena alasan keungan yang mempengaruhi kesuksesan dan kepuasan individu terhadap pension (Rosenkoetter, Garris, Eghdal, (2001). Oleh karena itu penelitian ini bertujuan untuk mengetahui peran faktor kepribadian dalam hal ini Core Self Evaluation sebagai prediktor persiapan pensiun pada karyawan.

Pensiun merupakan sebagai proses yang dimulai dengan perencanaan dan pengambilan keputusan beberapa waktu sebelum berakhirnya masa kerja individu (Behr, 1998). Beberapa literature menjelaskan persepsi terhadap pension merupakan suatu proses yang menandai persiapan diawal, individu melakukan persiapan pension jauh-jauh hari sebelum meningggalkan pekerjaan(Reitzes \& Mutran, 2004).

Menurut Muratore \& Earl ( 2010) persiapan pensiun merupakan besarnya usaha yang dilakukan oleh individu ketika masihmenjadi karyawan untuk menghasilkan kesejehteraan hidup pada masa pension. Individu yang melakukan usaha untuk menyiapkan pension adaalah individu yang mendekati perilaku persiapan aktual. Semakin besar usaha yang dilakukan individu maka semakin besar persiapan yang dilakukan, dan sebaliknya, semakin kecil usaha yang dilakukan individu atau sama sekali tanpa usaha maka semakin kecil intensi untuk melakukan persiapan pensiun. Beberapa penelitian menunjukan hubungan yang signifikan antara persiapan pensiun dengan kepuasan pensiun. Penelitan yang dilakukan oleh Mutran, Reitezes \& Fernandez (1997) membuktkan bahwa persiapan pensiun meningkatkan penyesuaian diri individu ketika memasuki masa pensiun.

Denton, dkk dalam ( Muratore \& Earl, 2010) persipan pensiun individu meliputi tiga aspek yaitu: (1) Asuransi diri (Self-Insurance), asuransi diri merupakan persiapan keuangan pribadi yang dilakukan individu untuk memaksimalkan kekayaan dikemudian hari. Perilaku ini meliputi menabung, investasi atau berkontribusi pada dana pension, mengikuti asuransi pribadi untuk asset mapun kesehatan. (2) Perlindungan Diri (Self Protection), yang merupakan aspek non financial yang dilakukan individu untuk mempertahankan kesehatan dan kesejahteraan dikemudian hari.Aspek ini meliputi melakukan atau memilih gaya hidup yang sehat, mengembangan jaringan dukungan social termasuk keluarga, dan memilih tempat tinggal di lingkungan yang sehat. (3) Perlindungan Umum (Public Protection) yaitu keuntungan yang diberikan oleh pemerintah untuk meningkatkan kesehatan, kekayaan dan kesejahteraan dikemudian hari. Aspek ini meliputi uang pension, program kesehatan umum, pelayanan kesehatan dan program perumahan.

Muratore \& Earl, 2010 menjelaskan bahwa beberpa faktor mempengaruhi persiapan pension pada individu, yaitu satu jenis kelamin. Petkoska \& Earl, 2009 membuktikan bahwa terdapat perbedaan usaha yang dilakukan oleh laki-laki dan perempuan dalam usaha persipan pension. Laki-laki lebih banyak melakukan persiapan financial sedangkan perempuan lebih banyak menghabiskan usaha untuk peningkatan kesehatan dan bersenang-senang. Faktor kedua yaitu usia, seiring dengan bertambahnya usia inidvidu terjadi peningkatan pemikiran tentang pensiun, perencanaan keuangan, perilaku menabung dan meluangkan waktu untuk membuat perencanaan pension Morgan \& Eckert (2004). Selain jenis kelamis dan usia, persiapan pension juga dipengaruhi oleh penghasila. Semakin tinggi penghasilan telah diprediksi berhubungan positif dengan besarnya 
usaha melakukan persiapan pension (Denton, dkk 2004). Faktor lain yang mempengaruhi adalah core self evaluation.

Core Self Evaluation (CSE) merupukan tingkatan dimana individu menyukai atau tidak menyukai diri sendiri, menganggap diri efektif, cakap dan mampu mengendalikan lingkungan (Judge, dkk , 2003). CSE mengandung empat elemen keribadian yaitu general self efficacy , self esteem, neuroticism dan locus of controlCSE menggabarkan keyakinan individu mengenai kemampuannya (untuk mengontrol hidupnya) dan kompetensinya (untuk berperilaku, mengatasi, gigih dan berhasil) dan perasaan kehidupannya akan berakhir baik oleh ditentukan oleh diri sendiri (Judge, 2009). Hasil penelitian telah menunjukkan bahwa CSE yang tinggi berhubunan positif dengan besarnya usaha persiapan pensiun dan melebihi variable demografis (Muratore \& Earl, 2010 ).

Dalam tahapan perkembangan karir individu, pension terjadi pada tahap akhir, dimana individu tidak lagi terlibat dalam peran maupun tanggung jawab pada organisasi. Sebagai bagian dari tahapan karir yang pasti akan dilalui individu, maka seharusnya individu sudah menyiapkan tahap ini sebelumnya. Besarnya usaha yang dilakukan individu untuk menyiapkan masa pensiunnya akan membantu individu untuk mencapai kesejahteraan pada masa pension. Beberapa penelitian membuktikan bahwa masa pensiun justru meningkatkan kepuasan dan kesejahteraan pada beberapa individu. Salah satu faktor yang dinilai berperan bagi individu dalam menghadapi masa pension adalah persiapan pension yang dilakukan. Individu yang melakukan persiapan pension menunjukkan usaha yang lebih untuk meningkatkan kesejahteraannya ketika pension jauh-jauh hari sebelum masa pensiunnya. Individu tersebut melakukan usaha-usaha yang bertujuan untuk memberikan perlindungan diri secara mandiri baik secara financial, non financial maupun pemanfaatan fasilitas dan program pemerintah bagi pensiunan atau manula.

Persiapan persiun didefinisikan sebagai besarnya usaha yang dilakukan oleh individu ketika masih menjadi karyawan untuk mencapai kesejahteraan hidup pada masa pension (Muratore \& Earl, 2005). Dapat diduga bahwa individu yang melakukan usaha untuk mempersiapkan pensiunnya akan mendekati perilaku persiapan pension yang sesungguhnya. Sebagaimana dijelaskan oleh Ajzen (1991) dalam teori tindakan terencana (Theory of Planned Behavior) faktor paling penting yang menentukan terbentunya perilaku pada individu adalah niat atau intensi.

Menurut Muratore \& Earl (2005) pengukuran mengenai intensi dapat mengukur secara langsung efektivitas intervensi pada penyebabnya, sebagai contoh intervensi yang bertujuan untuk meningkatkan sikap terhadap persipan pension membentuk norma subjektif pada tingkat yang sesuai terhadap persiapan pension dan meningkatkan persepsi terhadap kemampuan melukan kontrol terhadap persiapan pension. Persiapan pension merupakan perilaku yang direncanakan, artinya individu melakukan beberapa pertimbangan sebelum melakukannya. Sebagaimana dijelaskan dalam teori perilaku berencana, persiapan pension yang dilakukan individu ditentukan oleh besarnya intensi inidvidu untuk melakukan persiapan pensiunnya. Intensi yang dimiliki dipengaruhi oleh sikap, norma subjektif dan persepsi terhadap kemampuannya dalam melakukan kontrol (Ajzen, 1991). CSE merupakan sifat kepribadian yang berhubungan dengan kemampuan individu dalam melakukan kontrol terhadap perilakunya (Robbins dan Judge, 2006). CSE menggambarkan sejauh mana individu menyukai atau tidak menyukai diri sendiri, menganggap diri efektif, cakap dan mampu mengendalikan lingkungan. Individu yang memilki self esteem yang tinggi akan menghargai dirinya sendiri, penghargaan terhadap diri sendiri akan mendukung sikap yang positif terhadap perencanaan pension. Locus of control internal 
akan membuat individu lebih aktif dalam merencanakan pensiunnya (Morgan \& Eckert, 2004), lebih tenang, tidak mudah cemas ketika menghadapi tekanan (Judge, 2009). Indvidu dengan effikasi diri yang tinggi akan memandang bahwa dirinya mampu mengatasi kesulitan yang dihadapi pada masa pension serta memiliki keyakinan akan kemampuan diri dalam merencanakan pensiunya).

Masa transisi pensiunan merupakan situasi yang menekan dimana individu mengalami kehilangan peran, rentan memiliki persaan tidak memiliki peran yang penting Kim dan Moen (2001). Akan tetapi hal tersebut tidak membuat individu kehilangan penghargan diri yang dimiliki dan mampu menghadapi sehingga tidak mengarah pada tekanan psikologis. Meskipun terjadi penurunan fisik, kecapatan dan beberapa kemampuan lain seiring bertambahnya usia, keyakinan bahwa masa depan ditentukan oleh diri sendiri dan keyakinan akan kemampuan dirinya membuat ybs mampu melakukan usahausaha yang besar untuk mempersiapkan pensiunnya secara mandiri tanpa banyak tergantung pada pihak lain.

\section{METODE PENELITIAN}

Subjek penelitian ini adalah karyawan PT. $\mathrm{X}$ wilayah kerja Indonesia Blok Explorasi yang memasuki usia dewasa madya antara 50 - 55 tahun dan sudah memasuki masa pension (MPP) pada tahun 2013 dengan masa kerja antara 25 - 30 tahun. Metode pengumpulan data dalam penelitian ini adalah dengan menggunakan dua skala yaitu skala persiapan pension dan skala Core Self Evalution. skala persiapan pension merupakan adaptasi dari skala Retirement Planning Questioner Version II ( Muratore \& Earl, 2010) yang digunakan untuk mengukur besarnya usaha yang dilakukan individu untuk mempersiapkan pensiunnya. Skala ini terdiri atas 27 item dalam tiga aspek yaitu public protection, self insurance dan self protection. Hasil uji reliabilitas menunjukkan koefisien reliabilitas sebesar 0,889. Skala core self evaluation merupakan adaptasi dari skala Core Self Evaluation dari Judge, dkk (2003). Skala ini terdiri atas 12 item yang mengukur empat kompenen yaitu self esteem, general self efficacy, locus of control dan neuroticism, dengan koefisien reliabilitas sebesar 0,825.

\section{HASIL DAN PEMBAHASAN}

Hasil analisis regresi mengenai pengaruh core selfevaluation terhadap persiapan pension menunjukkan koefisien regresi $F=0,581$ dengan taraf signifikansi 0,679 $(p>0,05)$. Hal ini menunjukkan bahwa tidak ada pengaruh core self evaluation terhadap persiapan pension. Hasil analisis regresi pada masing-masing aspek, dapat diketahui bahwa pengaruh self esteem terhadap persiapan pension menunjukkan koefisien regresi $t=1,174$ dengan taraf signifikansi $0,246$ ( $p>0,05)$. Hal ini menunjukkan bahwa tidak ada pengaruh self esteem terhadap persiapan pension. Hasil analisis regresi pada aspek self effcacy terhadap persiapan pensiun menunjukkan koefisien regresi $t=1,119$ dengan taraf signifikansi 0,268 ( $\mathrm{p}>0,05)$. Hal ini menunjukkan bahwa tidak ada pengaruh self efficacy terhadap persiapan pensiun. Hasil analisis regresi pada aspek locus of control terhadap persiapan pensiun menunjukkan koefisien regresi $t=0,295$ dengan taraf signifikansi 0,796 ( $p>0,05)$. Hal ini menunjukkan bahwa tidak ada pengaruh locus of control terhadap persiapan pension Hasil analisis regresi pada aspek emotional stability terhadap persiapan pension menunjukkan koefisien regresi $\mathrm{t}=0,066$ dengan taraf signifikansi 0,948 ( $p>0,05)$. Hal ini menunjukkan bahwa tidak ada pengaruh emotional stability terhadap persiapan pension. Dengan demikian hipotesis yang diajukan dalam penelitian ini ditolak.

Hasil analisis regresi menunjukkan bahwa 
tidak ada pengaruh core self evaluation terhadap persiapan pension. Hal ini sejalan dengan penelitian Earl \& Moratore (2006) bahwa CSE tidak mempengaruhi besaranya usaha mempersiapkan pension pada aspek asuransi diri (self insurance ) dan perlindungan umum (public protection), dan hanya mempengaruhi pada aspek perlindungan diri (self protection). Perlindungan umum merupakan aspek yang terkait dengan fasilitas dan keutungankeuntungan lain yang disediakan pemerintah bagi para pensiunan, dengan demikian dimungkinkan bahwa pengertian diri yang positif (positive sense of self) tidak mempengaruhi individu untuk mengadopsi strategi dalam mempersiapkan pensiunnya, yang pada akhirnya berarti bahwa mereka bergantung pada pihak lain untuk keamanan mereka dimasa pension. Meskipun demikian, Earl \& Moratore (2006) menyebutkan bahwa terlalu dini untuk menyimpulkan bahwa CSE tidak berhubungan dengan asuransi diri, diperlukan penelitian lebih lanjut dengan sampel yang lebih besar untuk membuktikan CSE tidak mempengaruhi aspek asuransi diri dan perlindingan dirimengingat, perencanaan pensiun pada kedua aspek tersebut membutuhkan inisiatif dari individu.

Faktor lain yang juga mempengaruhi persiapan pension adalah sikap. Menurut Moorthy, dkk (2012) sikap terhadap pension memiliki peran penting terhadap persiapan pension yang dilakukan oleh individu. Sikap yang positif terhadap persiapan pension memungkinkan individu untuk mencapai penghasilan yang mencukupi dan relax. Menurut ajzen (2005) sikap dan sifat kepribadian memiliki peran penting dalam untuk memprediksi dan menjelaskan perilaku manusia. Sebagaimana dijelaskan oleh Fizben dan Ajzen dalam teori perilaku berencana, kepribadian mempengaruhi sikap individu terhadap situasi yang akan menentukan intensi individu untuk berperilaku, semakin kuat intensi individu semakin besar kemunculan perilaku yang diharapkan. Selain itu, intense juga ditentukan oleh norma subjektif individu terhadap perilaku dan kontrol atas perilaku. Intensi akan semakin kuat apabila perilaku yag dimunculkan sesuai dengan harapan orang-orang disekitarnya dan individu memiliki kendali untuk mengontrol perilakunya. Keterbatasan dalam penelitian ini adalah tidak melibatkan sikap dan norma subjektif sebagai faktor yang menentukan terbentuknya perilaku perencanaan pension sehingga tidak mampu memprediksi perilaku persiapan pension secara langsung.

Hal ini diasumsikan bahwa diperlukan terbentuknya sikap dan intensi terhadap persiapan pension untuk dapat membentuk perilaku persiapan pension. Beberapa penelitian membuktikan terdapat hubungan empiris yang kecil antara trait kepribadian dengan perilaku yang spesifik (Mitchel, dalamAjzen, 1991). Penelitian yang dilakukan oleh Werehim (1972) yang menemukan bahwa locus of control tidak mampu memprediksi pencapaian, dan keterlibatan politik (Leverson, 1981). Penelitian selanjutnya diharapkan melakukan penelitian mengenai sikap dan intensi untuk memprediksi peran trait kepribadian terhadap perilaku persiapan pension.

MenurutAjzen (2005) munculnya perilaku juga dipengaruhi oleh beberapa faktor-faktor non motivasional yaitu adanya kesempatan dan sumber daya seperti usia, kompetensi, dukungan dari pihak lain. faktor-faktor tersebut secara bersama-sama menggambarkan kontrol yang sebenarnya atas perilaku individu. Individu membutuhkan kesempatan dan sumberdaya yang mendukung. Hasil penelitian yang dilakukan oleh Moorthy, dkk (2012) menemukan bahwa generasi muda dari individu yang bekerja yaitu usia antara 26 - 35 tahun memiliki persepsi yang lebih baik terhadap perencanaan pensiun dan tidak khawatir dengan masa pensiun dibandingkan dengan kelompok usia yang lebih tua. Usia ini memandang bahwa perencanaan lebih dini untuk mempersiapkan masa pensiun 
dapat membawa keuntungan dan manfaat kepada mereka. Hal ini juga memungkinkan mereka untuk merencanakan dan mencapai tujuan atau mimpi mereka selama masa pensiun. Subjek dalam penelitian ini berusia antara 50 - 55 tahun, sehingga dimungkinkan kurang memiliki persepsi yang positif perencanaan pension. Hal ini yang menyebabkan subjek kurang melakukan usaha yang besar untuk mempersiaplan pensiunnya.

Moorthy, dkk (2012) juga menjelaskan bahwa faktor lain yang mempengaruhi persiapan pension adalah tingkat pendidikan. Semakin tinggi tingkat pendidikan individu semakin besar persiapan pension yang dilakukan. Hal ini terkait dengan aspirasi, wawasan yang dimiliki dan harapan akan kehidupan yang lebih baik dimasa yg akan datang. Subjek dalam penelitian ini sebagian besar memiliki tingkat pendidikan SMA, sehingga dimungkinkan memiliki keterbatasan aspirasi dan harapan dimasa yang akan datang sehingga kurang menunjukkan usaha yang besar untuk mempersiapkan pensiunnya.

Persiapan pension juga tidak dapat dilepaskan dari faktor budaya. Menurut Brodjonegoro \& Simandjuntak (2002) kuatnya hubungan kekeluargaan di Indonesia menyebabkan persiapan pension bukan merupakan hal yang familiar dikalangan masayarakat Indonesia dibandingkan dengan negara-negara industry lainnya. Sebagaimana negara dengan budaya yang dibangun atas hubungan primordial, genarasi muda dalam hal ini anak-anak bertanggung jawab terhadap generasi tua (orang tua) dalam kehidupan seharihari. Hal inilah yang dimungkinkan mempengaruhi intensi karyawan dalam mempersiapkan pensiunnya dan dapat menggantungkan hidupnya pada orang lain setelah masa pensiunnya.

\section{SIMPULAN}

Berdasarkan hasil analisis data penelitian maka dapat diambil kesimpulan diperoleh kesimpulan sebagai berikut tidak ada pengaruh core self evaluation terhadap persiapan pension pada karyawan. Persiapan pensiun tidak dapat dilepaskan dari faktor budaya. Negara dengan budaya yang dibangun atas hubungan primordial, memiliki pandangan bahwa genarasi muda dalam hal ini anak-anak bertanggung jawab terhadap generasi tua (orang tua) dalam kehidupan seharihari. Hal inilah yang dimungkinkan mempengaruhi intensi karyawan dalam mempersiapkan pensiunnya dan dapat diartikan bahwa mereka menggantungkan hidupnya pada oranglain setelah masa pensiunnya. Berdasarkan hasil penelitian, pembahasan dan kesimpulan yang telah diuraikan sebelumnya, peneliti menyampaikan beberapa saran di antaranya, bagi peneliti selanjutnya yang tertarik pada tema penelitian yang serupa diharapkan dapat meneliti variable persiapan pension dengan memperhatikan faktor intensi sebagai penentu perilaku. Penelitian selanjutnya hendaknya memperhatikan faktor-faktor non motivasional yang mempengaruhi persiapan pension seperti penghasilan, jenis kelamin, akses informasi yang dapat mempengaruhi persiapan pension. Selain itu penelitian selanjutnya hendaknya memperbesar sampel sehingga dapat mewakili populasi yang ada. Mengingat karyawan melakukan usaha yang cukup untuk mempersiapkan pensiunnya, perusahaan diharapkan dapat mendorong atau memfasilitasi agar karyawan melakukan usaha yang lebih secara mandiri untuk mempersiapkan pensiunnya.

\section{DAFTAR PUSTAKA}

Antolis, J.P.2007.Coping with the Challenges of Forced Retirement. Fire Engineering. August 2007.

Ajzen, I. 1991. Theory of Planned Behavior. Organizational Behavior and Human Decision Processes. 50, 179-211. 
Ajzen, I. 2005. Attitude, Personality and Behavior. Open University Press. England

Beehr, T.A. 1986. The process of retirement: A review and recommendations for future investigation. Personnel Psychology, 39, 31-55.

Brodjonegoro, B. \& Simandjuntak,R. 2002. Pensiun Plan In Indonesia: Avenues For Reform. Hitotsubashi Journal Of Economics 43 (2002), PP.151 - 161

Denton, M. A., Kemp, C. L., French, S., Gafni, A., Joshi, A. Rosenthal, C. J., et al. 2004. Reflexive planning for later life. Canadian Journal on Aging, 23, 7182.

Earl, J.K \& Muratore, A. 2000. UNSW Retirement Report 2009. Report Preparad For National Seniors Australia.

Earl, J.K \& Muratore, A. 2010. Predicting retirement preparation through the design of a new measure. Australian Psychologist, June 2010; 45(2): 98111.

Gill, S.C, dkk. 2006 Mental health and the timing of Men's retirement. Soc Psychiatry Psychiatr Epidemiol (2006) 41:515522.

Hurlock, E. B. 1980.Psikologi Perkembangan Suatu Pendekatan Sepajang Rentang Kehidupan, Jakarta: Erlangga.

Judge, T.A \& Bono, J.E. 2001 Relationship of Core Self-Evaluations Traits-SelfEsteem, Generalized Self-Efficacy, Locus of Control, and Emotional Stability-With Job Satisfaction and Job Performance: A Meta-Analysis. Journal of Applied Psychology
2001, Vol. 86, No. 1, 80-92

Judge, T.A 2009. Core Self-Evaluations and Work Success. Journal of the association for Psychological Science. Vol 18 number1

Kementerian Koordinator Bidang Kesejahteraan Rakyat . Lansia masa kini dan mendatang Situs Resmi Kementerian Koordinator Bidang Kesejahteraan Rakyat . Powered by Joomla! @copyright Copyright (C) 2005 Open Source MattersG. Aenll errigahtetsd :r e1s3e November, 2012, 06:54

Kim, J.E \& Moen, P. 2001. Is Retirement Good or Bad For Subjective Well-Being?. American Psychological Society. Volume 10.Number 3 June 2001

Levenson. H. 1981. Differentiating among internality, powerful others, and chance. In H.M. Lefcourt (Ed.), Research with the locus of control construct: Vol. 1. Assessment methods . New York: Academic Press.

Mein G, dkk. 2003 Is retirement good or bad for mental and physical health functioning? Whitehall II longitudinal study of civil servants. Journal Epidemiol Commun Health 57:46-49.

Moen P.1996. A life course perspective on retirement, gender, and well-being. Journal of Occupation Health Psychoogy 1:131-144

Moorthy, M.K, dkk. 2012. A study on the Retirement Planning Behavior of Working Individuals in Malaysia. International Journal of Academic Research in Economics and Management Sciences April 2012, Vol. 1, No. 2 
Morgan, L.A., \& Eckert, J. K. 2004. Retirement financial preparation: Implications for policy. Journal of Aging and Social Policy, 16, 19-34

Reitzes, D. C., \& Mutran, E. J. 2004. The transition to retirement: Stages and factors that influence retirement adjustment. International Journal of Aging and Human Development,59, 63-84.19, 251-273

Rosenkoetter, Garris, Eghdal.1998. Psychosocial Changes Following Retirement. Journal of advance Nursing. 1998. $27.966-976$
Sethepen, Fouqereau, Fernandez. 2008. The relationship between self determination and retirement satisfaction among active retired individual. International journal and human development. Vol 66(4) 329 - 345.

Warehime, R. G. 1972. Generalized expectancy for locus of control and academic performance.Psychological Reports, 30, 314.

Wotherspoon, J.C. (1995). Plan Naow, Enjoy Later? A study of the use and Effectiveness of Formal Retirement Planning Programs. Benefir Quarterly. First Quarter. 